4 Coloma, ${ }^{3}$ Javier Escobar, ${ }^{4}$ M. Consuelo Jiménez, ${ }^{1}$ Miguel A. Miranda ${ }^{11}$ and Inmaculada $5 \quad$ Andreu $^{* 3}$

6 1nstituto de Tecnología Química UPV-CSIC/ Departamento de Química, Universitat 7 Politècnica de València, Camino de Vera s/n, 46022 Valencia, Spain

${ }^{2}$ Unidad de Cultivos Celulares del IIS La Fe-UPV, Hospital Universitari i Politècnic La

9 Fe, Avenida de Fernando Abril Martorell 106, 46026 Valencia, Spain

\section{Enhanced Photo(geno)toxicity of Demethylated}

\section{Chlorpromazine Metabolites}

Fabrizio Palumbo, ${ }^{1}$ Guillermo Garcia-Lainez, ${ }^{2}$ Daniel Limones-Herrero, ${ }^{1}$ M. Dolores

Fe, Avenida de Fernando Abril Martorell 106, 46026 Valencia, Spain

${ }^{3}$ Unidad Mixta de Investigación IIS La Fe-UPV, Hospital Universitari i Politècnic La Fe, Avenida de Fernando Abril Martorell 106, 46026 Valencia, Spain

${ }^{4}$ Sabartech S L. Biopolo del IIS La Fe-UPV, Hospital Universitari i Politècnic La Fe, Avenida de Fernando Abril Martorell 106, 46026 Valencia, Spain

Corresponding author:

Email: Inmaculada Andreu - $\underline{\text { iandreur@qim.upv.es }}$

Miguel A. Miranda - $\underline{\text { mmiranda@qim.upv.es }}$

Keywords: Excited States, Laser Flash Photolysis, Metabolites, Photosensitized DNA Damage, Phototoxicity 


\section{INTRODUCTION}

23 Chlorpromazine (CPZ) is an anti-psychotic agent that belongs to the family of 24 phenothiazines. From a clinical standpoint, it is widely used to treat psychotic disorders such as schizophrenia or manic-depression. Unfortunately, CPZ has been often reported as photosensitizing agent, with undesirable side effects such as included phototoxic and photoallergic reactions in humans. ${ }^{1-8}$ In addition, CPZ photoproducts like promazine (PMZ) and chlorpromazine sulfoxide (CPZSO) have revealed toxic effects on primary cultures of hepatocytes. ${ }^{9}$ More recently, toxic epidermal necrolysis induced by CPZ upon sunlight exposure has been noticed. ${ }^{10}$ The phototoxic activity of drug can be related with their genotoxic and mutagenic potential. In this context, CPZ is able to promote DNA photodamage. $^{6,11,12}$

From the urine of psychiatric patients, CPZ metabolites have been identified ${ }^{13}$ revealing $^{2}$ that the metabolic pathways during Phase I led to demethylation, sulphoxidation and hydroxylation. ${ }^{14,15}$ Thus, biotransformation of CPZ results in a variety of derivatives, which have be considered for establishing the pharmacological and toxicological profile. $^{16}$

As a general rule, metabolism converts hydrophobic chemicals into more hydrophilic derivatives that can be easily eliminated through the urine. However, in certain cases, drug-metabolizing enzymes can also produce electrophilic metabolites that react with cellular macromolecules such as DNA, RNA, and proteins, causing cell death and organ toxicity. ${ }^{17}$

Assessment of the phototoxic potential of sunlight-absorbing drugs is highly recommended by Health authorities (FDA; EMEA) $)^{18,19}$ but the influence of metabolism is not considered in the appraisal. For that reason, identification of reactive drug 
<smiles>CN(C)CCCN1c2ccccc2Sc2ccc(Cl)cc21</smiles>

CPZ<smiles>CNCCCN1c2ccccc2Sc2ccc(Cl)cc21</smiles>

DMCPZ<smiles>NCCCN1c2ccccc2Sc2ccc(Cl)cc21</smiles>

DDMCPZ<smiles>CN(C)CCCN1c2ccccc2Sc2ccccc21</smiles>

PMZ<smiles>CN(C)CCCN1c2ccccc2S(=O)c2ccc(Cl)cc21</smiles>

CPZSO 


\section{MATERIALS AND METHODS}

\subsection{Chemicals.}

All solvents (HPLC grade) and reagents were commercially available and used without additional purification. Chlorpromazine, promazine, in vitro toxicology assay kit, neutral red based and DNA repair enzymes E. coli formamidopyrimidine DNA glycosylase (Fpg), E. coli endonuclease III (Endo III) were purchased from Sigma Aldrich (Madrid, Spain). Supercoiled circular pBR322 DNA, SYBR Safe DNA gel stain and DNA repair enzyme T4 endonuclease V (Endo V) were provided by Roche Diagnostics (Barcelona, Spain), Invitrogen (Madrid, Spain) and Ecogen (Barcelona, Spain), respectively. Phosphate buffered saline solution (PBS, $\mathrm{pH} 7.4,0.01 \mathrm{M}$ ) was prepared by dissolving Sigma tablets in the appropriate amount of deionized water. Reagent kit for single cell electrophoresis assay was supplied by Trevigen (Barcelona, Spain).

\subsection{Synthesis of Metabolites.}

Synthesis of DMCPZ was achieved in two-steps following the demethylation procedure described. ${ }^{20}$. In the first step, $\alpha$-chloroethyl chloroformate (ACE-Cl) was added to an ethylene dichloride solution of CPZ in order to form the intermediate ACE-CPZ, whose methanolysis afforded DMCPZ hydrochloride. As regards, DDMCPZ hydrochloride it was obtained by reduction of the 7-chlorophenothiazinyl nitrile using $\mathrm{LiAlH}_{4}$. Soxhlet extraction was performed in diethyl ether for 3 days, at $40{ }^{\circ} \mathrm{C}$ as in the original procedure described for a related compound. ${ }^{21}$ Finally, CPZSO was prepared from CPZ by oxidation in aqueous nitrous acid, at room temperature, following the method reported. ${ }^{22}$. All reactions were monitored by analytical TLC with silica gel 60 F254 and revealed with ammonium molybdate reagent. The crudes were purified through silica gel $60(0.063-2$ $\mathrm{mm}$ ). ${ }^{1} \mathrm{H}-\mathrm{NMR}$ and ${ }^{13} \mathrm{C}-\mathrm{NMR}$ spectra were recorded in $\mathrm{CDCl}_{3}$ or $\mathrm{CD}_{3} \mathrm{OD}$ as solvents on 
a Bruker AC-300 at 300 and $75 \mathrm{MHz}$ respectively; NMR chemical shifts are reported in ppm downfield from an internal solvent peak.

DMCPZ. ${ }^{1} \mathrm{H}-\mathrm{NMR}\left(300 \mathrm{MHz}, \mathrm{CD}_{3} \mathrm{OD}\right) \delta 2.19$ (m, 2H), 2.64 (s, 3H), 3.10 (m, 2H), 4.06 $(\mathrm{t}, J=6.3 \mathrm{~Hz}, 2 \mathrm{H}), 6.94-6.98(\mathrm{~m}, 1 \mathrm{H}), 7.00-7.11(\mathrm{~m}, 4 \mathrm{H}), 7.16-7.19(\mathrm{dd}, J=7.8,1.5$ $\mathrm{Hz}, 1 \mathrm{H}), 7.23$ - $7.28(\mathrm{~m}, 1 \mathrm{H}) .{ }^{13} \mathrm{C}-\mathrm{NMR}\left(75 \mathrm{MHz}, \mathrm{CD}_{3} \mathrm{OD}\right) \delta 24.7,33.7,45.2,48.2,117.4$, 117.6, 123.9, 124.6, 126.0, 127.0, 128.7, 129.0, 129.3, 134.7, 145.6, 147.9.

DDMCPZ. ${ }^{1} \mathrm{H}-\mathrm{NMR}\left(300 \mathrm{MHz}, \mathrm{CD}_{3} \mathrm{OD}\right) \delta 2.13(\mathrm{dq}, J=14.2,6.3 \mathrm{~Hz}, 2 \mathrm{H}), 2.98-3.09$ $(\mathrm{m}, 2 \mathrm{H}), 4.08(\mathrm{t}, J=6.4 \mathrm{~Hz}, 2 \mathrm{H}), 6.95-7.04(\mathrm{~m}, 2 \mathrm{H}), 7.04-7.10(\mathrm{~m}, 2 \mathrm{H}), 7.13(\mathrm{~d}, J=$ $8.2 \mathrm{~Hz}, 1 \mathrm{H}), 7.18(\mathrm{dd}, J=7.7,1.5 \mathrm{~Hz}, 1 \mathrm{H}), 7.25(\mathrm{ddd}, J=8.2,7.3,1.5 \mathrm{~Hz}, 1 \mathrm{H}) .{ }^{13} \mathrm{C}-\mathrm{NMR}$ (75 MHz, $\left.\mathrm{CD}_{3} \mathrm{OD}\right) \delta 26.0,38.6,45.2,117.4,117.6,123.9,124.6,126.1,127.0,128.6$, $128.9,129.3,134.7,145.7,148.0$.

CPZSO. ${ }^{1} \mathrm{H}-\mathrm{NMR}\left(300 \mathrm{MHz}, \mathrm{CDCl}_{3}\right) \delta 2.17(\mathrm{~m}, 2 \mathrm{H}), 2.37$ (s, 6H) 2.59 (m, 2H), 4.37 $(\mathrm{m}, 2 \mathrm{H}), 7.22-7.25(\mathrm{dd}, J=8.4,1.8 \mathrm{~Hz}, 1 \mathrm{H}), 7.30-7.32(\mathrm{dd}, J=7.8,1.2 \mathrm{~Hz}, 1 \mathrm{H}), 7.53$ $-7.55(\mathrm{~d}, J=8.1 \mathrm{~Hz}, 1 \mathrm{H}), 7.60-7.69(\mathrm{~m}, 2 \mathrm{H}), 7.85-7.88(\mathrm{~d}, J=8.4 \mathrm{~Hz}, 1 \mathrm{H}), 7.93-$ $7.95(\mathrm{dd}, J=7.8,1.5 \mathrm{~Hz}, 1 \mathrm{H}) .{ }^{13} \mathrm{C}-\mathrm{NMR}\left(75 \mathrm{MHz}, \mathrm{CDCl}_{3}\right) \delta 24.3,45.1,45.7,56.1,116.3$, $116.4,122.2,122.5,131.4,132.6,133.1,138.0,139.1,139.6$.

\subsection{Irradiation Equipment}

For all in vitro photosensitization assays, a photoreactor model LZC-4 (Luzchem, Canada) equipped with 14 lamps for top and side irradiation $\left(\lambda_{\max }=350 \mathrm{~nm}\right.$, Gaussian distribution) was used as the UVA light source. All irradiations were performed through the lid of the plates and the temperature was controlled by ventilation during the irradiation step.

\subsection{In Vitro 3T3 Neutral Red Uptake (NRU) Phototoxicity Test.}


BALB/c 3T3 fibroblasts cell line was grown in Dulbecco's Modified Eagle Medium

112 (DMEM) supplemented with $10 \%$ Fetal Bovine Serum (FBS), 4 mM glutamine and 1\% penicillin/streptomycin and routinely maintained in exponential growth in $75 \mathrm{~cm}^{2}$ plastic flasks in a humidified incubator at $37^{\circ} \mathrm{C}$ under $5 \%$ carbon dioxide atmosphere. The $3 \mathrm{~T} 3$ Neutral Red Uptake Phototoxicity Test was performed as previously described by the OECD guideline $432^{23}$ with minor modifications. Briefly, for each compound two 96wells plates were seeded $\left(2.5 \times 10^{4}\right.$ cells / well $)$. Cells were treated with test compounds at eight concentrations ranging from $0.5 \mu \mathrm{M}$ to $500 \mu \mathrm{M}$ and incubated for $1 \mathrm{~h}$. Next, one plate was irradiated on ice for $11 \mathrm{~min}$ to achieve a dose of UVA equivalent to $5 \mathrm{~J} / \mathrm{cm}^{2}$ (UVA LIGHT), whereas the other plate was kept in a dark box (DARK). The viability of UVA treated control cells was greater than $90 \%$ of those kept in the dark indicating the suitability of the UV dose. After irradiation the compound solutions were replaced with DMEM medium, and plates were incubated overnight. Next day neutral red solution (50 $\mu \mathrm{g} / \mathrm{mL}$ ) was added into each well and incubated for $2 \mathrm{~h}$. Cells were washed with PBS and neutral red was extracted in $100 \mu \mathrm{L}$ with the desorbs solution (water $49 \%$ (v / v), ethanol $50 \%(\mathrm{v} / \mathrm{v})$ and acetic acid $1 \%(\mathrm{v} / \mathrm{v})$. The absorbance was measured at $550 \mathrm{~nm}$ on a Multiskan Ex microplate reader. For each compound dose-response curves were developed in order to determine the concentration of compound causing a $50 \%$ reduction of the neutral red uptake $\left(\mathrm{IC}_{50}\right)$ in the absence and in the presence of radiation. Finally, the Photo-Irritation-Factor (PIF) was calculated using the following equation: PIF =

$131 \frac{\text { IC50 DARK }}{\text { IC50 UVA LIGHT }}$. According to the OECD Test Guideline ${ }^{23}$ a compound is predicted as 132 phototoxic if PIF is $>5$, probably phototoxic if PIF $>2$ and $<5$, and non phototoxic when $\mathrm{PIF}<2 . \mathrm{CPZ}$ and SDS were used as positive and negative controls, respectively. 
135 The drug $(\mathrm{CPZ})$ or its metabolites $(10 \mu \mathrm{M})$ in $10 \mu \mathrm{M}$ PBS at $\mathrm{pH} 7.4$ were added to 200 136 ng of supercoiled plasmid pBR 322 and mixtures were irradiated as described above. 137 After irradiation, loading buffer $(0.25 \%$ bromophenol blue, $0.25 \%$ xylene cyanol, $30 \%$ 138 glycerol 99\% in water) was added to each solution immediately. To reveal specific DNA 139 damages, irradiated mixtures were further incubated with an excess of DNA-repair enzyme (FPG, ENDO V or ENDO III) for $1 \mathrm{~h}$ at $37^{\circ} \mathrm{C}$, and loading buffer was then added to each solution. All the samples were loaded on a $0.8 \%$ agarose gel containing SYBR $®$ Safe as nucleic acid stain. Electrophoresis was performed in Tris-acetate-EDTA (TAE) buffer (0.004 M Tris-acetate, $1 \mathrm{mM}$ EDTA) at 100V for $1 \mathrm{~h}$. Finally, the DNA bands were detected under irradiation with UV light and visualized using a Gel Logic 200 Imaging System (Kodak). The relative abundance of the supercoiled form (Form I) and the nicked relaxed form (Form II) was quantified by densitometry with the image analyzer software Quantity One (BIO RAD).

\subsection{Assessment of Cellular DNA Damage by Comet Assay}

For the detection of strand breaks and alkaline labile sites, a single cell gel electrophoresis, also known as comet assay, has been performed as described by Collins A.R et al. ${ }^{24,25}$ with slight modifications. First, pre-coated slides were prepared by dipping degrease microscope slides in a hot $1 \%$ normal melting point agarose solution (1w:100v MiliQ water), air dried overnight at room temperature, and then stored at room temperature avoiding high humidity conditions (pre-coated slides can be stored more than two months).

The day of the experiment, fibroblasts (FSK) were trypsinized for $1 \mathrm{~min}$, and after seeding 250.000 cells $/ \mathrm{ml}$ in PBS per well in three 6-well plates, cells were placed on ice and allowed to stand for $2 \mathrm{~h}$ before incubating them with the different chemicals. We have found that trypsin by itself induces DNA damage in the FSK cells, and that it takes 2 
hours to recover basal levels. Then, FSK were incubated with $10 \mu \mathrm{M}$ PBS solutions of

Trevigen for $1 \mathrm{~h}$. After the incubation time, two 6-well plates were placed in a photoreactor to irradiate the cells with UVA light on ice for $5 \mathrm{~min}$, while $3^{\text {rd }}$ plate of cells were immediately prepared for comet assay without irradiation.

Thus, $30 \mu \mathrm{L}$ of each cell suspension were mixed carefully with $140 \mu \mathrm{L}$ of $37^{\circ} \mathrm{C} 0.8 \%$ low melting point agarose solution (1w:80v PBS- $\mathrm{Ca}^{2+/} \mathrm{Mg}^{2+}$ free) and drops of $5 \mu \mathrm{L}$ minigels were loaded on the slides. The coated-slides were placed on an ice-cold tray and twelve minigels were loaded onto each slide, being two replicates per condition. After loading, the minigels were allowed to gelify for $5 \mathrm{~min}$, followed by immersion of the slides in copling Jars containing cold lysis buffer $(\mathrm{NaCl} 2.5 \mathrm{M}$, Na2EDTA $0.1 \mathrm{M}$, Tris $10 \mathrm{mM}$, Triton $\mathrm{X}-1001 \%$ in distilled water and $\mathrm{pH} 10$ ) and overnight incubation at $4^{\circ} \mathrm{C}$. Next day, the covered with $850 \mathrm{~mL}$ of cold alkaline electrophoresis buffer $(200 \mathrm{mM} \mathrm{NaOH}, 1 \mathrm{mM}$ EDTA in distilled water and $\mathrm{pH} \geq 13$ ) and let during $40 \mathrm{~min}$ for DNA unwinding at $4^{\circ} \mathrm{C}$. Afterwards, the electrophoresis was run at $21 \mathrm{~V}(\approx 300 \mathrm{~mA})$ for $20 \mathrm{~min}$ at $4^{\circ} \mathrm{C}$. When the electrophoresis finished, the slides were neutralized twice in PBS for 5 min and washed once with miliQ water for $1 \mathrm{~min}$; DNA was fixed by slides incubation in $70 \%$ ethanol for 5 min followed by other $5 \mathrm{~min}$ in $100 \%$ ethanol, and then air-dried.

Comet nucleoids and tails were stained by incubating the slides in a SYBR Gold ${ }^{\circledR}\left(1: 10^{4}\right.$ nucleoids and tails DNA visualization, a distilled water drop and a cover slip were applied onto each slide and placed under an epi-fluorescence microscope with an UV-filter and $\geq 5$ pictures were taken for each sample. Finally, visual scoring was applied for DNA damage 
quantification for a total of 100 hundred DNA comets. ${ }^{26}$ Total comet score (TCS) was calculated by using a classification of 6 DNA damage categories ${ }^{26}$ and the following formula: $\left[\left(\mathrm{N}_{\text {class } 0}\right.\right.$ comets x 0$)+\left(\mathrm{N}_{\text {class } 1}\right.$ comets $\left.\times 1\right)+\left(\mathrm{N}_{\text {class } 2}\right.$ comets $\left.\times 2\right)+\left(\mathrm{N}_{\text {class } 3}\right.$ comets $\mathrm{x} 3)+\left[\left(\mathrm{N}_{\text {class } 4}\right.\right.$ comets $\left.\mathrm{x} 4\right)+\left(\mathrm{N}_{\text {class } 5}\right.$ comets x 5$)+\left(\mathrm{N}_{\text {class } 6}\right.$ comets x 6) $] / 6$ and expressing results in $1-100$ arbitrary units.

\subsection{Steady-State Photolysis.}

Ultraviolet absorption spectra were recorded on a Varian Cary 300 scan UV/Vis spectrophotometer. Irradiation of CPZ and its demethylated metabolites was carried out at monochromatic wavelength $(330 \mathrm{~nm})$ using a Xenon lamp. The progress of reactions was monitored following changes in emission spectra $\left(\lambda_{\operatorname{exc}}=330 \mathrm{~nm}\right)$. Steady-state fluorescence experiments were carried out in the wavelength range 350-650 nm using an EasyLife X (Optical Building Blocks) spectrofluorometer, equipped with a monochromator PTI. Measurements were performed in PBS $\left(5 \times 10^{-5} \mathrm{M}\right)$ at room temperature using $1 \mathrm{~cm}$ quartz cells with $3.5 \mathrm{~mL}$ capacity under anaerobic conditions.

2.8 Laser Flash Photolysis. Laser flash photolysis (LFP) experiments were done with a pulsed $\mathrm{XeCl}$ excimer laser $\left(\lambda_{\mathrm{exc}}=308 \mathrm{~nm}, \mathrm{ca} .17 \mathrm{~ns}\right.$ pulse width, $<100 \mathrm{~mJ}$ per pulse $)$ as the excitation source. In general, samples received only one pulse for all kinetic experiments. A pulsed Lo255 Oriel Xenon lamp was used as detecting light source. The observation wavelength was selected with a 77200 Oriel monochromator, and the signal amplified by an Oriel photomultiplier tube (PMT) system made up of a 77348 side-on tube, 70680 housing, and a 70705 power supply. The signal was registered with a TDS640A Tektronix oscilloscope and subsequently transferred to a personal computer. Concentrations of the samples were fixed by adjusting the absorbance of the solutions at the arbitrary value of 0.3 at the excitation wavelength. All transient spectra were recorded 
using $1 \mathrm{~cm}$ quartz cells with $3.5 \mathrm{~mL}$ capacity at room temperature under aerobic conditions.

2.9 EPR Spin Trapping Measurements. The experiments were done in a flat cell with a Bruker EMX 10/12 EPR spectrometer, using the following parameters: microwave power, $20 \mathrm{~mW}$; modulation amplitude, $1.0 \mathrm{G}$; and modulation frequency, $100 \mathrm{kHz}$. As spin-trap 2-methyl-2-nitrosopropane (MNP) was employed. Thus, analysis was performed recording the EPR signal of the MNP adduct of the aryl radical generated by loss of the chlorine atom from $\mathrm{CPZ}$ or its metabolites. Anaerobic PBS solutions containing the same concentration (1.4 mM) of MNP and CPZ (or one of its metabolites) were irradiated at $330 \mathrm{~nm}$ by means of a Xenon lamp for $3 \mathrm{~min}$.

\section{RESULTS AND DISCUSSION}

\subsection{Phototoxicity.}

220

Cell viability of the CPZ metabolites and photoproducts in combination with UVA light was assessed by the in vitro $3 \mathrm{~T} 3$ NRU phototoxicity test. Thus, cytotoxicity profiles of BALB/c 3 T3 fibroblasts cell treated with CPZ, PMZ, CPZSO, DMCPZ, DDMCPZ were measured in the presence of absence of UVA light, using neutral red as vital dye.

This test is based on the calculation of the PIF that corresponds to the ratio of the $\mathrm{IC}_{50}$ for each chemical with and without UVA irradiation. The values obtained are given in Table 1.

Table 1. In vitro 3T3NRU phototoxicity assay of CPZ metabolites and photoproducts. 


\begin{tabular}{|c|c|c|c|}
\hline Compound & IC $_{\mathbf{5 0}}$ Dark $(\boldsymbol{\mu M})$ & $\begin{array}{c}\mathbf{I C}_{\mathbf{5 0}} \text { UVA Light } \\
(\boldsymbol{\mu M})\end{array}$ & $\begin{array}{c}\text { Photoirritant } \\
\text { Factor (PIF) }^{\mathbf{a}}\end{array}$ \\
\hline $\mathrm{CPZ}$ & $78.6 \pm 15.3$ & $2.9 \pm 0.6$ & $\mathbf{2 7}$ \\
\hline $\mathrm{PMZ}$ & $113.6 \pm 18.5$ & $6.6 \pm 2,5$ & $\mathbf{1 7}$ \\
\hline $\mathrm{CPZSO}$ & $78.5 \pm 2.7$ & $25.2 \pm 5.0$ & $\mathbf{3 5}$ \\
\hline $\mathrm{DMCPZ}$ & $60.9 \pm 9.4$ & $1.8 \pm 0.6$ & $\mathbf{3 7}$ \\
\hline $\mathrm{DDMCPZ}$ & $66.9 \pm 5.6$ & $1.8 \pm 0.3$ & $\mathbf{1}$ \\
\hline $\mathrm{SDS}$ & $202 \pm 25$ & $244 \pm 48$ & $\mathbf{3}$ \\
\hline
\end{tabular}

Data represent Mean \pm SD from five independent experiments. CPZ and SDS were used as positive and negative control of phototoxicity, respectively. according to the OECD (2004), PIF $<2$ means "No Phototoxicity", 2<PIF<5 means "Probably Photototoxicity" and PIF $>5$ means "Phototoxicity".

The $\mathrm{IC}_{50}$ were determined from dose-response curves for cell viability of cell treated with chemicals under light or dark conditions. More details are provided in Supplementary Material. assay. $3 \mathrm{~T} 3$ cells were treated with serial dilutions of $\mathrm{CPZ}$ metabolites ranging from 0.5 
$\mu \mathrm{M}$ to $500 \mu \mathrm{M}$ for $1 \mathrm{~h}$, followed by irradiation or not of a dose of $5 \mathrm{~J} / \mathrm{cm}^{2} \mathrm{UVA}$ light. CPZ

242 was used as a positive control of phototoxicity ${ }^{27}$ After 24 h cell viability was evaluated by neutral red uptake and $\mathrm{IC}_{50}$ values were calculated by non-lineal regression with GraphPad Prism 5.0. Data represent Mean \pm SD from five independent experiments and asterisks significant differences relative to the $\mathrm{IC}_{50}$ Dark by the T-Student test $(* * \mathrm{p} \geq$ $0.01 ; * * * \mathrm{p} \geq 0.001)$.

As shown in Table 1 and Figure 2, CPZ was clearly phototoxic as expected, while promazine (dechlorinated photoproduct of CPZ) resulted less toxic upon irradiation with

a PIF of $c a$. 17. However, DMCPZ and DDMCPZ resulted be more phototoxic (a 1.6fold increase of the $\mathrm{IC}_{50}$ ) than the parent drug. Both $\mathrm{CPZ}$ and its demethylated metabolites DMCPZ and DDMCPZ display the same chromophore. Therefore, the different behavior shown in phototoxic assays may be modulated by the alkyl chain for the lipophilicity /hydrophilicity of the different substrates. By contrast, the CPZSO metabolite did not exhibit any phototoxic potential. These results are in agreement with those obtained from the in vivo phototoxicity study by means of mouse-tail technique. ${ }^{28}$

\subsection{Photosensitized DNA Damage}

It is well known that phototoxicity involves damage to biomolecules. In particular photosensitized DNA damage is of interest since it plays an important role in photogenotoxicity and may induce lethal mutagenic and/or carcinogenic effects. ${ }^{29,} 30$ Hence, irradiations of $\mathrm{CPZ}$ and its metabolites were performed in the presence of supercoiled circular DNA (pBR322) to detect DNA damage. Single strand breaks (ssb) can be observed directly whereas to reveal the nature of base damage the use of DNArepair enzymes is needed. 
A)

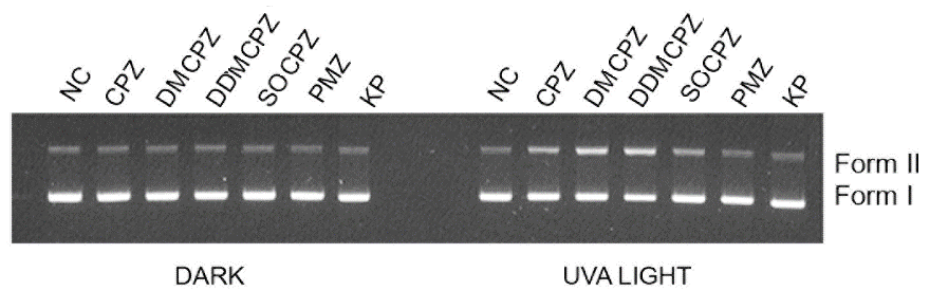

B)

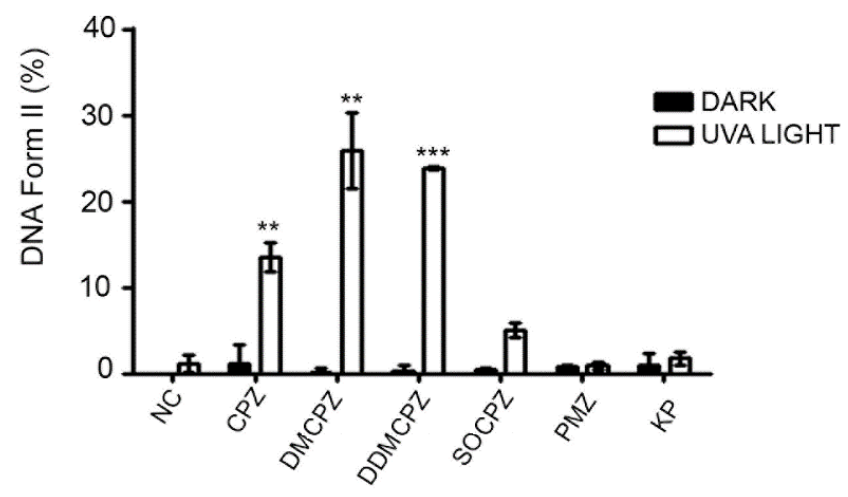

266 Figure 3. Photogenotoxicity of CPZ and its metabolites. (A) Agarose gel 267 electrophoresis of supercoiled DNA (pBR322, $200 \mathrm{ng} / \mu \mathrm{L}$ ) alone or in the presence of $268 \mathrm{CPZ}$ and its metabolites $(10 \mu \mathrm{M})$ in the dark or upon irradiation (5 min) using a multilamp 269 photoreactor $\lambda_{\max }=355 \mathrm{~nm}$. NC: Negative Control, KP: ketoprofen used as standard. (B) 270 Formation of DNA Form II quantified by densitometry. Data represent Mean \pm SD from 271 three independent experiments and asterisks significant differences relative to the 272 formation of DNA Form II in Dark conditions by the T-Student test (**p $\geq 0.01 ; * * * p \geq$ 273 0.001). The initial value of Form II was subtracted from all samples.

275 Agarose gel electrophoresis (Figure 3 A) revealed a conversion of native supercoiled form

276 I into circular form II, indicating ssb formation. Interestingly, quantification by 277 densitometry of form II showed that DMCPZ and DDMCPZ display higher 278 photogenotoxic potential than the parent drug (Figure $3 \mathrm{~B}$ ). The DMCPZ and DDMCPZ 279 metabolites resulted to be more hydrophilic and reactive than the parent drug, 280 demonstrating that $\mathrm{CPZ}$ metabolism modulates the potential to photosensitize DNA damage. 
282 Different DNA-repair enzymes Endo III, Fpg and Endo V were used in order to reveal oxidized pyrimidines, oxidized purines and cyclobutane thymine dimers, respectively. In all cases, ssb formation was accentuated for DMCPZ and DDMCPZ metabolites (data reported in Supplementary Material).

\subsection{Photogenotoxicity detected by Comet Assay}

Comet assay under alkaline conditions was performed to reveal the combination of single-

CPZ, DMCPZ and DDMCPZ. After 5 min of UVA exposure and immediate lysis, fragmented DNA migrates away from the nucleus. Upon staining with SYBR Gold the

A)

FSK

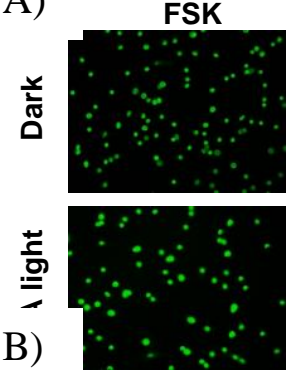

CPZ

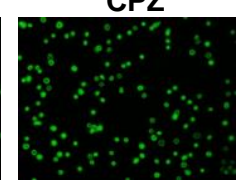

DMCPZ

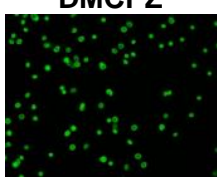

DDMCPZ
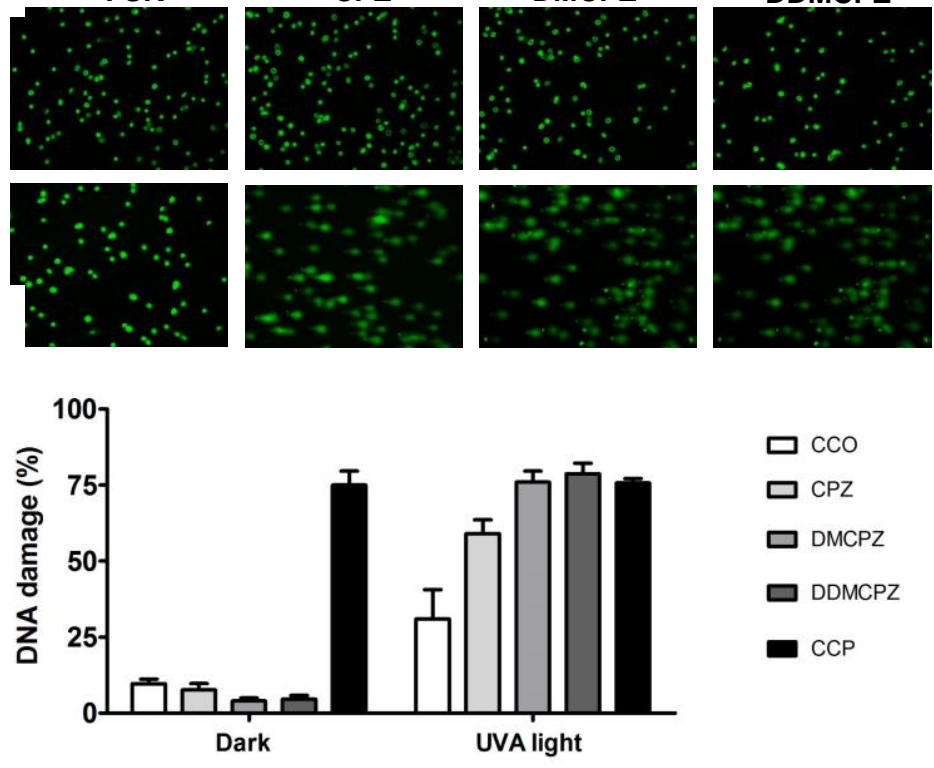

upon UVA irradiation. (B) Percentage of DNA damage obtained for chemicals tested calculated by means of 6 DNA damage categories. $\mathrm{CCO}$ and $\mathrm{CCP}$ were used as positive and negative control, respectively.

As shown in Figure 4, comet assays confirmed the damage induced by CPZ and its 303 metabolites to cellular DNA, as fragmented DNA moves faster through agarose gel, forming a tail. These results are in agreement with CPZ metabolites displaying a higher photogenotoxic potential than the parent drug.

\subsection{Photophysical Studies}

\subsubsection{Absorption Spectra}

308

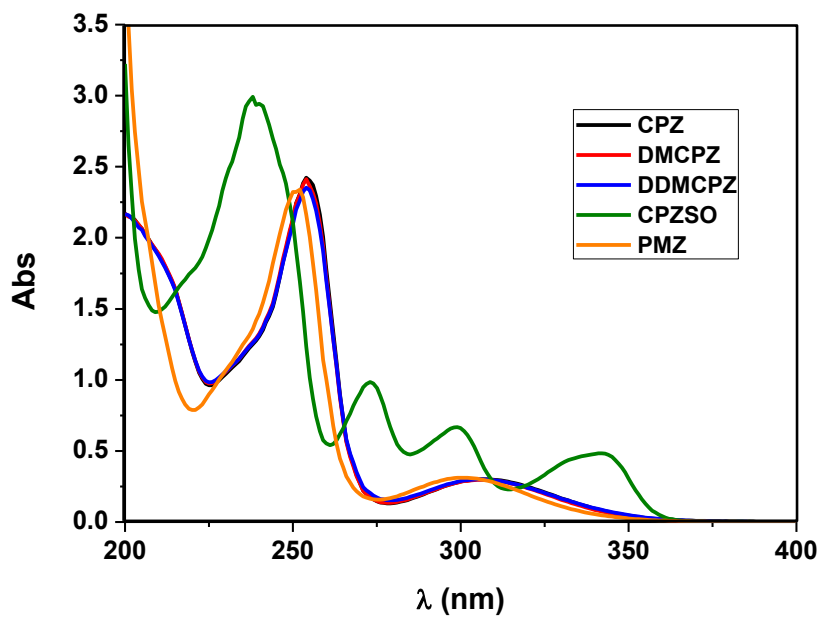

Figura 5. UV absorption spectra of CPZ, DMCPZ, DDMCPZ, CPZSO and PMZ in PBS at $5 \times 10^{-5} \mathrm{M}$. 


\section{$317 \quad$ 3. 4.2 Laser Flash Photolysis Studies}

318 The transient absorption spectra of CPZ $\left(\lambda_{\mathrm{exc}}=308 \mathrm{~nm}\right.$, air, flow cell $)$ were recorded in 319 MeCN (as model of lipophilic environment) and in aqueous medium (PBS). The 320 normalized spectra are shown in Figure 6. The absorption band in MeCN exhibited a 321 maximum at $\lambda=470 \mathrm{~nm}$, attributed to the triplet excited state, in agreement with literature 322 data. ${ }^{31,32}$ However, the maximum in PBS appeared at $\lambda=520 \mathrm{~nm}$, and was due to the 323 CPZ radical cation. ${ }^{33-37}$ In aqueous medium, DMCPZ and DDMCPZ, exhibited both 324 contributions from the triplet excited state and the radical cation. The decay traces monitored at $\lambda=470 \mathrm{~nm}$ (PBS, air) showed that the triplet lifetimes values of the three compounds were in the submicrosecond domain and increased with the methylated 327 degree (Figure 6B).

A)

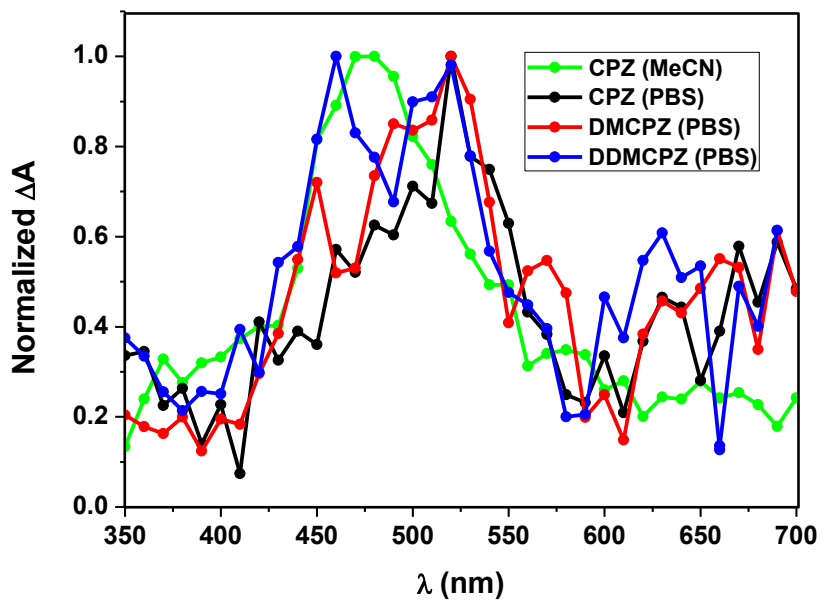


B)

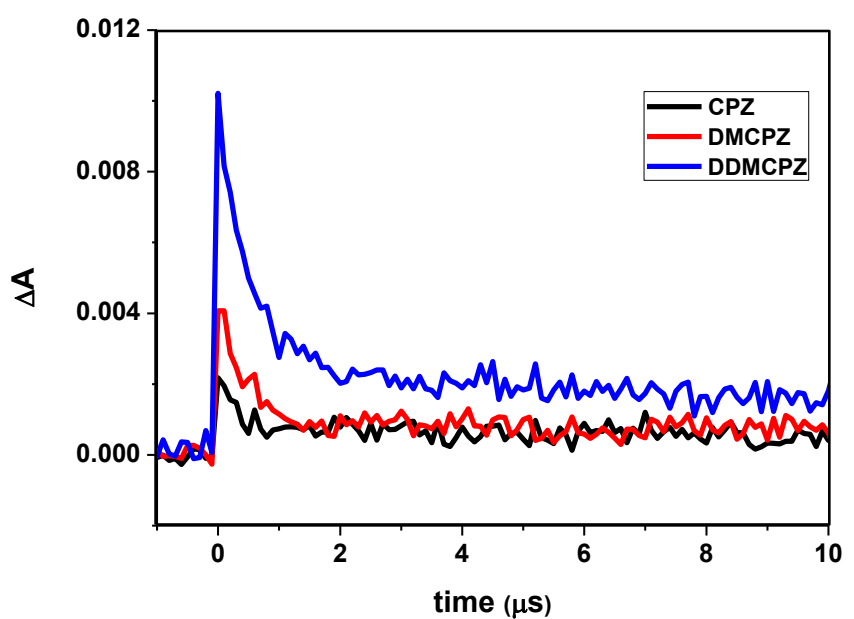

Figure 6. Laser flash photolysis ( $\lambda_{\mathrm{exc}}=308 \mathrm{~nm}$, air) of CPZ and its metabolites. (A): Normalized spectra of CPZ in MeCN (green), CPZ in PBS (black), DMCPZ in PBS (red) and DDMCPZ in PBS (blue), recorded $0.2 \mu$ s after the laser pulse. (B): Normalized decay traces monitored at $\lambda=470 \mathrm{~nm}$ in PBS/air.

\subsubsection{Steady-State Photolysis}

The course of the photoreaction of CPZ $\left(\lambda_{\text {irr }}=330 \mathrm{~nm}\right.$, PBS $)$ was followed by monitoring the changes in its fluorescence spectra. The initial emission of CPZ $\left(\lambda_{\text {exc }}=330 \mathrm{~nm} / \mathrm{PBS}\right)$ consisted of a band centered at $460 \mathrm{~nm}$ with quantum yield lower than 0.005 . The fluorescence bands of the photomixtures were located in the same region, but their intensity increased with irradiation times (Figure 7). This is in agreement with the occurrence of a photodehalogenation reaction, leading to the corresponding promazines, whose fluorescence quantum yields are much higher. A comparison of the fluorescence intensity changes at $500 \mathrm{~nm}$ with irradiation times showed a similar trend for CPZ, DMCPZ and DDMCPZ (Figure 7B). 
A)

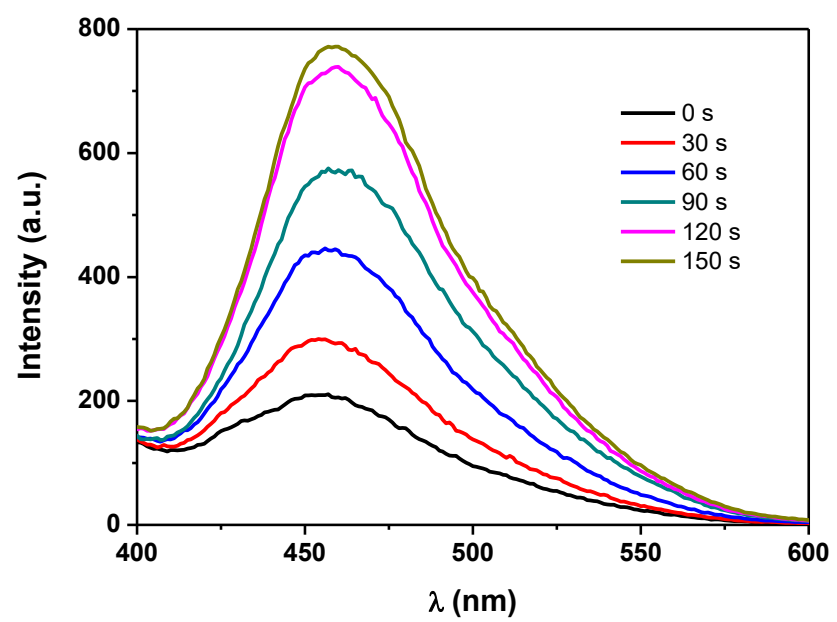

B)

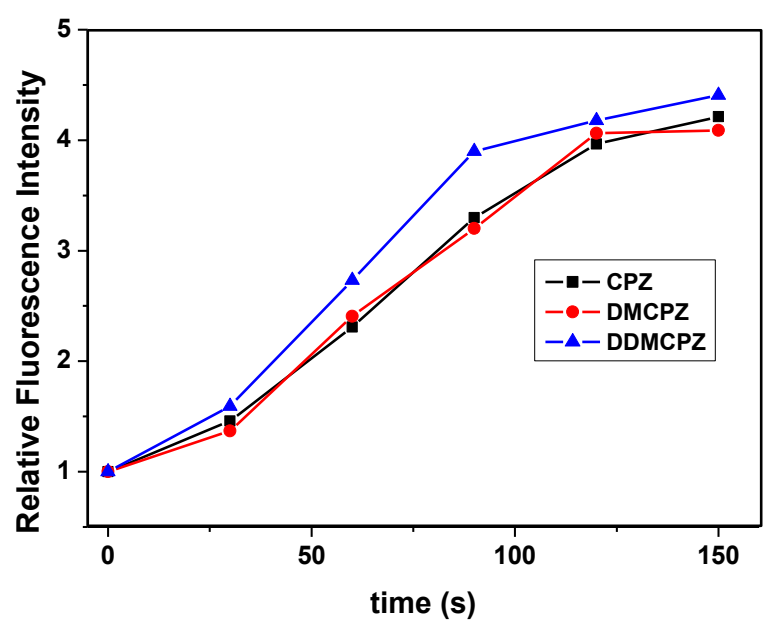

347 Figure 7. Monitorization of irradiations by fluorescence. Conditions: $\lambda_{\text {irr }}$ and $\lambda_{\text {exc }}=330 \mathrm{~nm}, 5 \times$ $10^{-5}$, PBS, air; (A) Spectra obtained after irradiation of CPZ from 0 to $150 \mathrm{~s}$; (B) Fluorescence intensity values at $\lambda=500 \mathrm{~nm}$ for CPZ (black), DMCPZ (red) and DDMCPZ (blue) at different irradiation times.

\section{Electron Paramagnetic Resonance}

352 To confirm the presence of intermediates of radical nature, an EPR study was performed.

353 As a matter of fact, the spin adducts obtained from 2-methyl-2-nitrosopropane (MNP) 354 and the aryl radicals of CPZ, DMCPZ and DDMCPZ were observed in all cases (Figure 355 8). This is in agreement with the photodehalogenation reaction, initiated by homolytic 356 cleavage of the $\mathrm{C}-\mathrm{Cl}$ bond. 


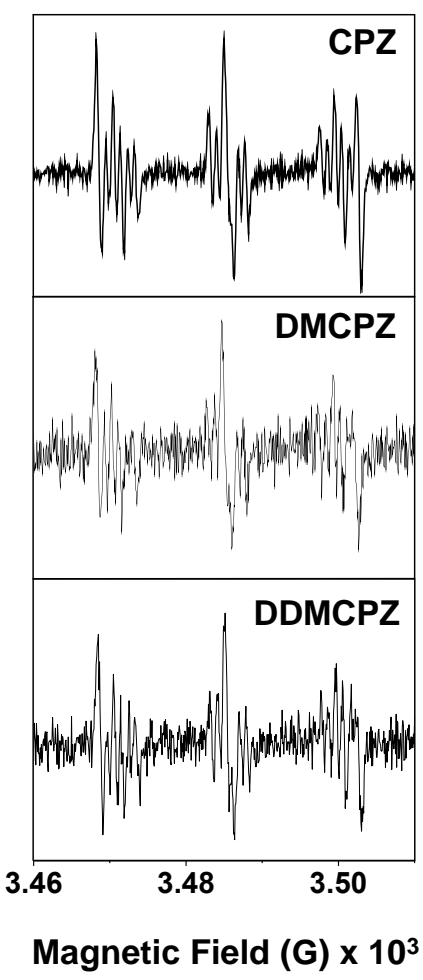<smiles>[R2]N([R2])CCCN1c2ccccc2Sc2ccccc21</smiles><smiles>[R2]N([R])CCCN1c2ccccc2Sc2ccc(N([O-])C(C)(C)C)cc21</smiles>

CPZ $\quad \mathrm{R}_{1}=-\mathrm{CH}_{3}, \mathrm{R}_{2}=-\mathrm{CH}_{3}$

DMCPZ $\mathrm{R}_{1}=-\mathrm{H}, \mathrm{R}_{2}=-\mathrm{CH}_{3}$ DDMCPZ $R_{1}=-H, R_{2}=-H$

358 Figure 8. EPR spectra of MNP adduct of aryl radical from CPZ, DMCPZ and DDMCPZ 359 in $\mathrm{H}_{2} \mathrm{O}\left(\lambda_{\text {exc }}=330 \mathrm{~nm}, \mathrm{~N}_{2}\right)$. The concentrations of drug/metabolite and MNP were 1.4 $360 \mathrm{mM}$ in all cases.

Acknowledgements

Miguel Servet Contract for I. A. and FPU fellowship for F.P. is gratefully acknowledged.

Funding

This work was supported by the Carlos III Institute of Health (Grants: RD12/0013/0009 and CP11/00154) and the Generalitat Valenciana (Prometeo Program). of Man to Light. Annual Review of Medicine 14, 195-214. 
(2) Satanove, A., and McIntosh, J. S. (1967) PHototoxic reactions induced by high doses of

(3) Epstein, J. H., Brunsting, L. A., Petersen, M. C., and Schwarz, B. E. (1957) A Study of

Photosensitivity Occurring with Chlorpromazine Therapy11Presented at the Seventeenth Annual Meeting of The Society for Investigative Dermatology, Inc., Chicago, Illinois, June 10, 1956. Journal of Investigative Dermatology 28, 329-338.

(4) Johnson, B. E. (1974) Cellular mechanisms of chlorpromazine photosensitivity. Proceedings of the Royal Society of Medicine 67, 871-873.

(5) Ljunggren, B., and Moller, H. (1977) Phenothiazine phototoxicity: an experimental study on chlorpromazine and related tricyclic drugs. Acta dermato-venereologica 57, 325-329.

(6) Kochevar, I. E., Chung, F.-L., and Jeffrey, A. M. (1984) Photoaddition of chlorpromazine to DNA. Chemico-Biological Interactions 51, 273-284.

(7) Motten, A. G., Buettner, G. R., and Chignell, C. F. (1985) SPECTROSCOPIC STUDIES OF CUTANEOUS PHOTOSENSITIZING AGENTS-VIII. A SPIN-TRAPPING STUDY OF LIGHT INDUCED FREE RADICALS FROM CHLORPROMAZINE and PROMAZINE. Photochemistry and Photobiology 42, 9-15.

(8) Beijersbergen van Henegouwen, G. M. J. (1997) Medicinal Photochemistry (phototoxic and phototherapeutic aspect of drugs).

(9) Castell, J. V., José Gómez-Lechón, M. A., Miranda, M. A., and Morera, I. M. (1987) Toxic effects of the photoproducts of chlorpromazine on cultured hepatocytes. Hepatology 7 , 349-354.

(10) Huang, H.-T., Chang, C.-L., and Tzeng, D.-S. (2010) Toxic epidermal necrolysis after sunexposure probably due to lamotrigine and chlorpromazine. Asian Journal of Psychiatry 3, 240-242.

(11) De Mol, N. J., and Busker, R. W. (1984) Irreversible binding of the chlorpromazine radical cation and of photoactivated chlorpromazine to biological macromolecules. ChemicoBiological Interactions 52, 79-92.

(12) Viola, G., Latterini, L., Vedaldi, D., Aloisi, G. G., Dall'Acqua, F., Gabellini, N., Elisei, F., and Barbafina, A. (2003) Photosensitization of DNA Strand Breaks by Three Phenothiazine Derivatives. Chemical Research in Toxicology 16, 644-651.

(13) Beckett, A. H., Beaven, M. A., and Robinson, A. E. (1963) Metabolism of chlorpromazine in humans. Biochemical Pharmacology 12, 779-794.

(14) Hartmann, F., Gruenke, L. D., Craig, J. C., and Bissell, D. M. (1983) Chlorpromazine metabolism in extracts of liver and small intestine from guinea pig and from man. Drug Metabolism and Disposition 11, 244-248.

(15) Chetty, M., Moodley, S. V., and Miller, R. (1994) Important Metabolites to Measure in Pharmacodynamic Studies of Chlorpromazine. Therapeutic Drug Monitoring 16, 30-36.

(16) Wójcikowski, J., Boksa, J., and Daniel, W. A. (2010) Main contribution of the cytochrome P450 isoenzyme $1 A 2$ (CYP1A2) to $\mathrm{N}$-demethylation and 5-sulfoxidation of the phenothiazine neuroleptic chlorpromazine in human liver-A comparison with other phenothiazines. Biochemical Pharmacology 80, 1252-1259.

(17) Pearson, P. G., and Wienkers, L. C. (2009) Handbook of Drug Metabolism, 2nd Ed.

(18) EMEA. (2002) Note for guidance on photosafety testing.

(19) FDA, C. (2003) Guidance for industry photosafety testing.

(20) Kitamura, K., Fujitani, K., Takahashi, K., Tanaka, Y., Hirako, S., Kotani, C., Hashimoto, T., and Takegami, S. (2000) Synthesis of [N-13CH3] drugs (chlorpromazine, triflupromazine and promazine). Journal of Labelled Compounds and Radiopharmaceuticals 43, 865-872.

(21) Zhou, Z., Franz, A. W., Bay, S., Sarkar, B., Seifert, A., Yang, P., Wagener, A., Ernst, S., Pagels, M., Müller, T. J. J., and Thiel, W. R. (2010) Redox Active Mesoporous Hybrid Materials by In situ Syntheses with Urea-linked Triethoxysilylated Phenothiazines. Chemistry - An Asian Journal 5, 2001-2015. 
(22) Owens, M. L., Juenge, E. C., and Poklis, A. (1989) Convenient oxidation of phenothiazine salts to their sulfoxides with aqueous nitrous acid. Journal of Pharmaceutical Sciences 78, 334-336.

(23) OECD. (2004) OECD Guidelines for the Testing of Chemicals Test No. 432: In Vitro 3T3 NRU Phototoxicity Test (Original Guideline, adopted 13th April 2004).

(24) Azqueta, A., and Collins, A. R. (2013) The essential comet assay: a comprehensive guide to measuring DNA damage and repair. Archives of Toxicology 87, 949-968.

(25) Collins, A. R., El Yamani, N., Lorenzo, Y., Shaposhnikov, S., Brunborg, G., and Azqueta, A. (2014) Controlling variation in the comet assay. Frontiers in Genetics 5.

(26) Møller, P. (2006) Assessment of reference values for DNA damage detected by the comet assay in human blood cell DNA. Mutation Research/Reviews in Mutation Research 612, 84-104.

(27) Nathalie, D., Yannick, G., Caroline, B., Sandrine, D., Claude, F., Corinne, C., and PierreJacques, F. (2006) Assessment of the phototoxic hazard of some essential oils using modified 3T3 neutral red uptake assay. Toxicology in Vitro 20, 480-489.

(28) Ljunggren, B., and Möller, H. (1977) Phenothiazine Phototoxicity: an Experimental Study on Chlorpromazine and its Metabolites. Journal of Investigative Dermatology 68, 313317.

(29) Loveday, K. S. (1996) Interrelationship of Photocarcinogenicity, Photomutagenicity and Phototoxicity. Photochemistry and Photobiology 63, 369-372.

(30) Klecak, G., Urbach, F., and Urwyler, H. (1997) Fluoroquinolone antibacterials enhance UVA-induced skin tumors. Journal of Photochemistry and Photobiology B: Biology 37, 174-181.

(31) García, C., Oyola, R., Piñero, L. E., Arce, R., Silva, J., and Sánchez, V. (2005) Substitution and Solvent Effects on the Photophysical Properties of Several Series of 10-Alkylated Phenothiazine Derivatives. The Journal of Physical Chemistry A 109, 3360-3371.

(32) Navaratnam, S., Parsons, B. J., Phillips, G. O., and Davies, A. K. (1978) Laser flash photolysis study of the photoionisation of chlorpromazine and promazine in solution. Journal of the Chemical Society, Faraday Transactions 1: Physical Chemistry in Condensed Phases 74, 1811-1819.

(33) Joshi, R., Ghanty, T. K., and Mukherjee, T. (2008) Reactions and structural investigation of chlorpromazine radical cation. Journal of Molecular Structure 888, 401-408.

(34) Rosenthal, I., Ben-Hur, E., Prager, A., and Riklis, E. (1978) PHOTOCHEMICAL REACTIONS OF CHLORPROMAZINE; CHEMICAL AND BIOCHEMICAL IMPLICATIONS. Photochemistry and Photobiology 28, 591-594.

(35) Piette, J., Decuyper, J., Merville-Louis, M.-P., and Van De Vorst, A. (1986) Molecular, Cellular and Medical Aspects of PhotosensitizationBiomolecular photoalterations mediated by phenothiazine derivatives. Biochimie 68, 835-842.

(36) Nath, S., and Sapre, A. V. (2001) Photoinduced electron transfer from chloropromazine and promethazine to chloroalkanes accompanied by cleavage of $\mathrm{C}-\mathrm{Cl}$ bond. Chemical Physics Letters 344, 138-146.

(37) Garcia, C., Smith, G. A., McGimpsey, W. G., Kochevar, I. E., and Redmond, R. W. (1995) Mechanism and Solvent Dependence for Photoionization of Promazine and Chlorpromazine. Journal of the American Chemical Society 117, 10871-10878. 